\title{
Modeling distribution of Phoneutria bahiensis (Araneae: Ctenidae): an endemic and threatened spider from Brazil
}

\author{
Marcelo A. Dias ${ }^{1,2}$; Miguel Simó ${ }^{1,4}$; Ismael Castellano' \& Antonio D. Brescovit ${ }^{3}$ \\ 1 Sección Entomología, Facultad de Ciencias, Universidad de la República. Iguá 4225, CP 11400, Montevideo, Uruguay. \\ ${ }^{2}$ Centro de Ecologia e Conservação Animal, Universidade Católica de Salvador. Avenida Pinto de Aguiar 2589, Pituaçu, \\ 41740-090 Salvador, BA, Brazil. \\ ${ }^{3}$ Laboratório de Artrópodes, Instituto Butantan. Avenida Vital Brasil 1500, 05503-900 São Paulo, SP, Brazil. \\ ${ }^{4}$ Corresponding author. E-mail: simo@fcien.edu.uy
}

\begin{abstract}
Phoneutria bahiensis Simó \& Brescovit, 2001 is a large ctenid spider inhabiting the states of Bahia and Espírito Santo, Brazil. Considering that it is probably endemic, this species was included in the Brazilian red book of threatened species. Here, we predict the distribution range of $P$. bahiensis using 19 bioclimatic variables in the model design. The most septentrional record for this spider was indicated for northern Bahia. The model predicts that the distribution range covers the Atlantic Forest from the state of Paraíba to Rio de Janeiro, with the best suitable area in the Atlantic Forest of the state of Bahia. The bioclimatic variable with the best contribution to the model was precipitation in the driest quarter. Based on collected data, the species inhabits Ombrophilous Forests and Restinga vegetation, two ecosystems of the Atlantic Forest biome. In the best-predicted area of distribution, eleven Conservation Units were included. This information could be considered for future conservation plans of this species.
\end{abstract}

KEY WORDS. Atlantic Forest; niche modeling; bioclimatic variables; spider distribution.

Species distribution models (SDMs) have been used to predict the potential distribution of living organisms, linking records or species abundance with environmental constrains or spatial characteristics (Guisan \& Zimmermann 2000, Elith \& LeATHWick 2009). The models can be used to provide understanding and generate predictions about species distributions across a landscape. It has been successfully applied to terrestrial, freshwater and marine organisms in studies investigating the conservation and management of species, conservation of areas with high biodiversity, and studies on biogeography, invasive species and global climate change (CARROLL 2010, GALLIEN et al. 2010, Franklin 2010, Benito et al. 2009, De Mas et al. 2009, Elith \& Leathwick 2009, Ferrier et al. 2002, Guisan \& ZimmermanN 2000). The great demand for these kinds of ecological studies has promoted the development of several SDMs computer-based programs using different algorithms that search for accuracy of a given model and the best prediction power (FIELDING \& BeLL 1997). While knowledge on the distributional ranges of species is clearly needed, the ranges of most species either remain largely unknown or are incomplete, and most of the available studies are based on records from museum specimens, which may be biased (STOcKMAn et al. 2006).

Regarding environmental constrains, SDMs based on climate variables are considered useful tools for proposing criteria to select strategic areas for the conservation of species (AcOsTA 2008, Ruвio et al. 2010). Based on the expected climate toler- ance of a species, it is possible to predict the potential distribution area for that species when considering all field sites with similar climate conditions (ACOSTA 2008). Furthermore, these models can be used for species with few geographic records and scarce information on natural history (GuIsan \& Zimmermann2000, Brito et al. 2009, BAASch et al. 2010) and are therefore very important when making decisions regarding the conservation of threatened species and preservation of biodiversity (BRoокs et al. 1999).

Although the evaluation of climate constraints do not take into consideration other variables that may restrict geographic distributions, for instance habitat accessibility, vegetation, competition, predation, parasitism, dispersal and population genetics, the limitations to the distribution of many species are often significantly associated with climate (PARMESAN 2006, SEXTON et al. 2009). Moreover, climate constraints represent one of the most consistent predictors for the successful establishment of diverse taxa of plants and poikilothermic animals (ANDREWARTHA \& Birch 1984, Woodward 1987, Vink et al. 2011).

Sample size has been an important limitation for the performance evaluation of distribution models of species. The accuracy of the general model increases as the sample size becomes larger (Wisz et al. 2008). Studies based on small samples bring a greater degree of uncertainty to the estimation of parameters and consider fewer biological factors that may influence the relationships between species and their environment 
(CILIBERTi et al. 2009). Still, relatively few records may be enough to characterize the distribution of species with narrow environmental tolerances (KADMON et al. 2003). In this sense, good predictions were obtained with modeling algorithms based on few geographic records and scarce information on natural history (Pearson et al. 2007, Brito et al. 2009, Kumar \& Stohlgren 2009 , BAASCH et al. 2010). These models have been applied successfully in the design of conservation plans for rare species (Guisan et al. 2006).

Published studies on the distribution of species of spiders using SDMs are scarce. STOCKMAN et al. (2006) used the program GARP to predict the spatial distribution of three species of trapdoor spiders of Promyrmekiaphila Schenkel, 1950 (Cyrtaucheniidae) in California, USA. They used several types of variables including soil, temperature, altitude, precipitation and vegetation. Studies based only upon climatic variables have also been successfully applied to spiders. VINK et al. (2011) studied the current and world potential distribution and impacts of the invasive species Latrodectus hasseltii Thorell, 1870 (Theridiidae) using the program CLIMEX. Rubio et al. (2010) analyzed the potential distribution range of Dubiaranea difficilis (Mello-Leitão, 1944) (Linyphiidae) in Argentina based on relatively few locality records using Maxent.

The Neotropical Phoneutria Perty, 1833 includes eight species of large wandering spiders which are considered to be of medical importance due to the neurotoxic effects of their venom (Simó \& Brescovit 2001, Martins \& Bertani 2007). The genus is distributed from Central America to the northern Argentina (Simó \& BRESCOvit 2001, PlatnICK 2010) in three main areas: one from Central America to northeastern South-America, through the Andes, which includes Colombia, Ecuador, Peru, and Bolivia; a second area, situated in the Amazon region; and a third covering northeastern and southern Brazil, northern Argentina and Paraguay (MARTINS \& BerTANI 2007).

Phoneutria bahiensis Simó \& Brescovit, 2001 was described from specimens collected from different sites of the Atlantic Forest biome in the state of Bahia, northeastern Brazil. DiAs et al. (2005a) and BraziL et al. (2009) reported new field records from Bahia. Martins \& BERTANI (2007) indicated the southernmost record in the state of Espírito Santo. Compared to congeners, $P$. bahiensis has the most restricted distribution and is represented by relatively few specimens in arachnological collections. Owing to the few literature records for this species (DiAs et al. 2005a), the knowledge about the natural history of $P$. bahiensis is scarce. This spider has nocturnal activity and inhabits shrubs, litter and bromeliads (MACHADo et al. 2008). Its restricted geographic distribution suggests that this spider is endemic to only a part of the Atlantic Forest biome. This characteristic has promoted the inclusion of $P$. bahiensis in the Brazilian Environmental Ministry threatened species Red List (MMA 2008). However, the scarce data on the geographic distribution and biology of $P$. bahiensis is a rather weak support for its conservation status.
The distribution patterns of Phoneutria spp. have not been studied. Similarly, the factors which have restricted their distributional range have not been investigated. As demonstrated in previous studies on spiders and other invertebrates, temperature and humidity are likely the two most important variables that constrain ecological niches. Taking into account the important qualities of the tools used by SMDs in several studies, and the scarce application of this methodology in spiders, the main objectives of this study were to predict the geographical distribution of $P$. bahiensis based on climatic variables and to analyze its potential occurrence in Conservation Units in Brazil, an important contribution to the future management plans for this species.

\section{MATERIAL AND METHODS}

\section{Occurrence data}

Twenty-three records of $P$. bahiensis were analyzed: 22 from the state of Bahia and one from the state of Espírito Santo. The records were obtained from the literature (SIMÓ \& BRESCOVIT 2001, Martins \& Bertani 2007, Brazil et al. 2009) and from recently collected specimens (by M.A.D.) in Mata de São João, in the Northern coast of the state of Bahia, Brazil. The specimens were deposited in the following institutions: Instituto Butantan, São Paulo, São Paulo (IBSP), Universidade Federal of Bahia, Salvador, Bahia (UFBA) and Centro de Ecologia e Conservação Animal of the Universidade Católica do Salvador, Bahia (ECOA), all in Brazil.

\section{Records}

BRASIL, Bahia: Ilhéus $14^{\circ} 47^{\prime} 51^{\prime \prime}$ S, 3902'13”W, 1 male (IBSP 19027); 1 female (IBSP 19040); 1 male (IBSP 19344); 1 female (IBSP 24057); 1 female (IBSP 22076); 1 female (UFBA/LAP-A 172); Ilhéus, $14^{\circ} 47^{\prime} 20^{\prime \prime} \mathrm{S}, 39^{\circ} 02^{\prime} 58^{\prime \prime} \mathrm{W}, 1$ male (UFBA/LAP-A 173); 1 female (UFBA/LAP-A 1317); Itapebi $15^{\circ} 57^{\prime} \mathrm{S}, 39^{\circ} 32^{\prime} \mathrm{W}, 1$ male (IBSP 58193); 2 males 2 females (ECOA 00709); Porto Seguro $16^{\circ} 26^{\prime} 59^{\prime \prime} \mathrm{S}, 3^{\circ} 03^{\prime} 53^{\prime \prime} \mathrm{W}, 1$ female (IBSP 9516); Una, Reserva Biológica de Una, $15^{\circ} 16^{\prime} 20.08^{\prime \prime}$, 39 $9^{\circ} 03^{\prime} 54.88^{\prime \prime} \mathrm{W}, 1 \mathrm{fe}-$ male (IBSP 45022); 1 male (IBSP 45023); 1 male (IBSP 45024); Lomanto Júnior, $14^{\circ} 81^{\prime} \mathrm{S}, 39^{\circ} 47^{\prime} \mathrm{W}, 1$ female (IBSP 2427). Salvador: $12^{\circ} 58^{\prime} \mathrm{S}, 38^{\circ} 30^{\prime} \mathrm{W}, 1$ male (IBSP 58194); Parque Zoobotânico $\left(13^{\circ} 00^{\prime} 31^{\prime \prime} \mathrm{S}, 38^{\circ} 30^{\prime} 15^{\prime \prime} \mathrm{W}\right), 1$ female (UFBA/LAPA 1098); Parque Metropolitano da Lagoa e Dunas do Abaeté (12 $\left.56^{\prime} 41^{\prime \prime} \mathrm{S}, 38^{\circ} 21^{\prime} 22^{\prime \prime} \mathrm{W}\right) 1$ female (UFBA/LAP-A 872). Espírito Santo: Linhares, Reserva Particular do Patrimônio Natural Recanto das Antas, $19^{\circ} 23^{\prime} \mathrm{S}, 40^{\circ} 04^{\prime} \mathrm{W}, 1$ female (IBSP 7585).

New record: Bahia: Mata de São João, Praia do Forte, $12^{\circ}$ 33'S, 3859'W, 1 female (ECOA 01061); 1 female (ECOA 01062); 1 male (ECOA 01063); (12 $\left.52^{\prime} \mathrm{S}, 38^{\circ} 29^{\prime} \mathrm{W}\right), 1$ female (ECOA 01064). Three females were collected with pitfall traps and one male was captured by diurnal hand collection, during the fauna rescue program before the construction of a hotel complex, in Praia do Forte, Mata de São João city, at the Northern coast of Bahia. 


\section{Climatic variables}

We used the climatic database Wordclim 2.5 arc minutes with a resolution of $4.4 \mathrm{~km}$ (Hijmans et al. 2005a) that comprises nineteen different bioclimatic variables related to temperature and precipitation, from 1950 to 2000 . These variables can be used for mapping and spatial modeling with GIS programs, since they are potentially useful to represent the ecophysiological tolerances of a species in the habitat (GraHam \& Hijmans 2006). The dataset was analyzed with the geographic information system Diva Gis 7.1.7 (HiJMAns et al. 2005b).

\section{Modeling procedure}

The model was elaborated with Maxent, a maximum entropy based program that estimates the probability of a species occurrence based on the actual presence points and defined environmental constraints (PhiLLIPs et al. 2006). The output of Maxent model is a continuous map and a threshold must be set in order to determine the probability of a species' presence. To estimate the major incidence variables within the model we carried out a jackknife analysis to measure the weight of each variable. This method evaluates the importance of each variable when compared to all other variables.

Maxent has been used in the prediction and mapping of potential distribution areas for threatened species, where monitoring and restoration of native population in the natural habitat are necessary (GASTON 1996). Furthermore, this program works well with small sample sizes (Hernández et al. 2006, PeArson et al. 2007, Benito et al. 2009, Kumar \& Stohlgren 2009).

The program was used applying the "equal training sensitivity plus specificity" threshold rule (Liv et al. 2005) and the following settings: 1000 maximum interactions, random test percentage of $25 \%$, logistic output formatted, remove duplicates from the same gridcell. The total area modeled was situated between the following coordinates: latitude $2^{\circ} 48^{\prime} 19.46^{\prime \prime} \mathrm{S}$ to $23^{\circ} 18^{\prime} 12.89^{\prime \prime} \mathrm{S}$, longitude $32^{\circ} 20^{\prime} 41.51^{\prime \prime} \mathrm{W}$ to $44^{\circ} 32^{\prime} 03.42^{\prime \prime} \mathrm{W}$. Mapping was obtained by importing the model from the geographic information system DIVA-GIS, version 7.1.7 (HIJMANS et al. 2005a). We selected the option auto features that allow automatic limiting of feature types for small sample sizes.

For model evaluation we performed the Maxent function Receiver Operating Characteristic (ROC) (HANLEY \& McNeil 1982), frequently used in the evaluation of distribution models based in presence-absence algorithms (Benito de PANDo \& PeÑas de Giles 2007). This analysis considers the entire sample (training data as the $75 \%$ of the sample) and the $25 \%$ of the random sample (test data). The area under the receive operating characteristic curve (AUC) is an unbiased measure of prediction accuracy calculated from the ROC and represents the average sensitivity over all possible specificities, where AUC values close to 1 indicate the best discrimination (Zhonglin et al. 2009). Another evaluation of the model was performed in Diva Gis by calculating the AUC in a ROC plot. This analysis was based on $70 \%$ of the original points that were randomly re-sampled as training data to perform 20 iterations of the model (ACOsta 2008, RuBio et al. 2010).

\section{RESULTS}

\section{Bioclimatic analysis and habitat}

Table I summarizes the bioclimatic tolerance range of $P$. bahiensis, where only four bioclimatic variables influenced the model distribution. The variable with the highest contribution to the predicted range shape was "precipitation in the driest quarter" (BIO 17, 80,1\%), which occurs in the study area between August and October (end of Winter and beginning of Spring). The other three variables were related to temperature, but with lower contribution to the model. The "mean monthly temperature range ${ }^{\prime \prime}$ (BIO 2) in the predicted core area was between 21 and $29.4^{\circ} \mathrm{C}$. The species lives within an area where seasonality is not very marked, mainly with warm climate and with an annual mean temperature (BIO 1) that reaches $25.2^{\circ} \mathrm{C}$ (INMET 2009). Considering the collection data, this species lives in Restinga and Ombrophilous Forest, two Atlantic Forest ecosystems (Rizzini 1997). No records were from other areas with high anthropic influence such as urban environments or agroecosystems or activities related with transportation.

Table I. Contribution of the 19 bioclimatic variables to the distribution model of $P$. bahiensis. (PC) Percentage of contribution.

\begin{tabular}{llr}
\hline & \multicolumn{1}{c}{ Bioclimatic variables } & PC \\
\hline BIO 17 & Precipitation of driest quarter & 80.1 \\
BIO 2 & Mean monthly temperature range & 14.2 \\
BIO 1 & Annual mean temperature & 3.0 \\
BIO 3 & Isothermality & 2.7 \\
BIO 4 & Temperature seasonality & 0.0 \\
BIO 5 & Maximum temperature of warmest month & 0.0 \\
BIO 6 & Minimum temperature of coldest month & 0.0 \\
BIO 7 & Temperature anual range & 0.0 \\
BIO 8 & Mean temperature of wettest quarter & 0.0 \\
BIO 9 & Mean temperature of driest quarter & 0.0 \\
BIO 10 & Mean temperature of warmest quarter & 0.0 \\
BIO 11 & Mean temperature of coldest quarter & 0.0 \\
BIO 12 & Annual precipitation & 0.0 \\
BIO 13 & Precipitation of wettest month & 0.0 \\
BIO 14 & Precipitation of driest month & 0.0 \\
BIO 15 & Precipitation seasonality & 0.0 \\
BIO 16 & Precipitation of wettest quarter & 0.0 \\
BIO 18 & Precipitation of warmest quarter & 0.0 \\
BIO 19 & Precipitation of coldest quarter & 0.0 \\
\hline
\end{tabular}

\section{Distribution climatic model}

The predicted area of distribution for $P$. bahiensis indicated by the model covered the Atlantic Rainforest biome between states of Paraíba (07 $06^{\prime} 41.47^{\prime \prime}$ S, $\left.34^{\circ} 51^{\prime} 48.08^{\prime \prime} \mathrm{W}\right)$ and Rio de Janeiro $\left(22^{\circ} 45^{\prime} 42.01^{\prime \prime} \mathrm{S}, 42^{\circ} 54^{\prime} 16.38^{\prime \prime} \mathrm{W}\right)$. In the distribution 
model, the presence was set over the 0.227 logistic thresholds, and the algorithm converged after 100 iterations. The AUC test for training Data performed in Maxent was 0,971. The AUC values obtained in DIVA-GIS after 20 iterations fluctuated from 0.934 to 0.980 (mean 0.9684 ).

The highest suitability occurrence was concentrated between two sites in the state of Bahia, on the North, the city of Salvador, and on the South, the Reserva Biológica de Una, between 13 degrees and 15 degrees South of latitude and between 38 degrees and 39 degrees West of longitude along $260 \mathrm{~km}$ of the Atlantic Rainforest (Fig. 1). Salvador has Ombrophilous Forests and Restinga vegetation, while Una has only the former. Other potential areas with good predictions of distribution were located on Restinga vegetation. They are situated to the South of the state of Bahia, in the islands of the Parque Nacional Marinho de Abrolhos (1754'19.94"S, 38 52'19.92"W) and the city of Caravelas $\left(17^{\circ} 42^{\prime} 47.69^{\prime \prime} \mathrm{S}, 39^{\circ} 14^{\prime} 53.70^{\prime \prime} \mathrm{W}\right)$ and to the North, on the coastal region of the state of Sergipe, near Aracajú $\left(10^{\circ} 54^{\prime} 34.25^{\prime \prime} \mathrm{S}, 37^{\circ} 04^{\prime} 29.31^{\prime \prime} \mathrm{W}\right)$ and the metropolitan region of Recife (state of Pernambuco) (08 $\left.03^{\prime} 14^{\prime \prime} \mathrm{S}, 34^{\circ} 52^{\prime} 51^{\prime \prime} \mathrm{W}\right)$. The predicted area in Espírito Santo was characterized by the Ombrophilous Forest.

Considering the climatic variables, the unsuitable areas appear to be those outside of the coastal region and towards the center of the state, which present different climatic conditions in comparison with the Atlantic Rainforest, as well other types of vegetation such as Caatinga or Cerrado.

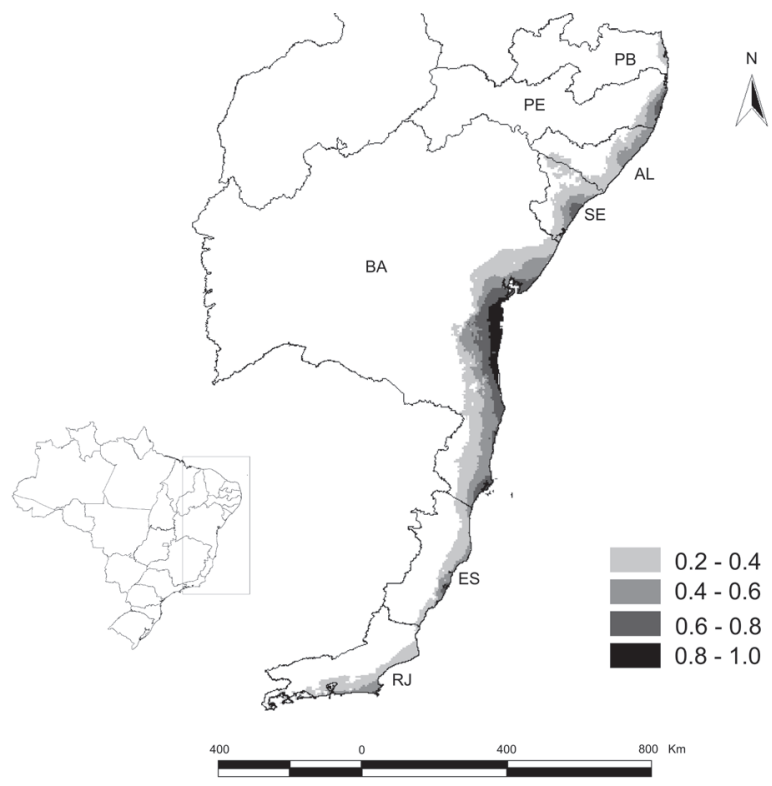

Figure 1. Potential predicted range of $P$. bahiensis in the Atlantic Forest biome, Eastern Brazil. Circles indicate the known records. (BA) Bahia, (ES) Espírito Santo, (RJ) Rio de Janeiro, (SE) Sergipe, (AL) Alagoas, (PE) Pernambuco, (PB) Paraíba.
Figure 2 shows that $P$. bahiensis was previously collected in four Conservation Units from the state of Bahia: Parque Metropolitano da Lagoa e Dunas do Abaeté and Parque Zoobotânico in Salvador, Área de Proteção Ambiental do Litoral Norte, Mata de São João, and Reserva Biológica de Una. Based on the predicted model, six Conservation Units are included in the most suitable distribution areas for the species: Parque Metroplitano de Pituaçu and Parque Joventino Silva in Salvador; Reserva da Vida Silvestre de Una, Parque Estadual Serra do Conduru, Reserva Extrativista de Canavieiras and Parque Nacional Marinho de Abrolhos in southern Bahia. In Espírito Santo, the species was collected in Linhares, and the record was included in the Reserva Particular do Patrimônio Natural Recanto das Antas.

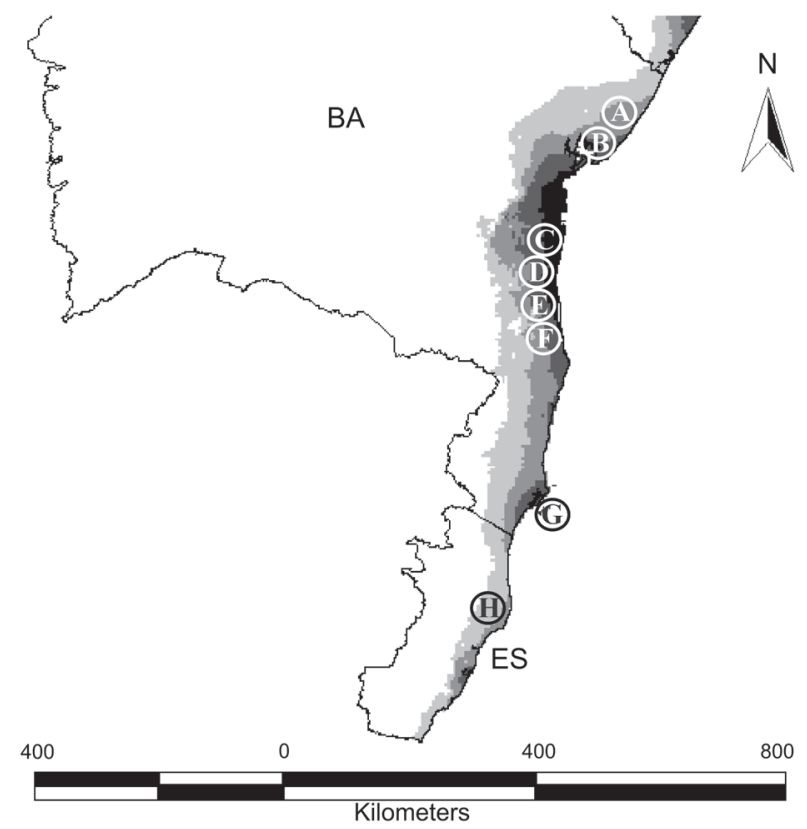

Figure 2. Conservation Units in the predicted distribution range of Phoneutria bahiensis. Bahia: (A) Área de Proteção Ambiental do Litoral Norte; (B) Fragmentos Florestais de Salvador: Parque Metropolitano da Lagoa e Dunas do Abaeté, Parque Metropolitano de Pituaçu, Parque Zoobotânico de Salvador; (C) Parque Estadual Serra do Conduru; (D) Reserva da Vida Silvestre de Una; (E) Reserva Biológica de Una; (F) Reserva Extrativista de Canavieiras; (G)= Parque Nacional Marinho de Abrolhos. Espírito Santo: (H) Reserva Particular do Patrimônio Natural Recanto das Antas.

\section{DISCUSSION}

Phytosociology studies indicate that annual precipitation has a direct effect on the primary productivity of ecosystems associated to the Atlantic Forest (LONDSDALE 1988, PIRES et al. 2006, ScheEr et al. 2009). The countryside of the state of Bahia features 
a total annual accumulated precipitation of $500 \mathrm{~mm}$, contrasting with the coast of the Atlantic Forest, where $1200 \mathrm{~mm}$ of rain fall per year (MARENGO 2008). Furthermore, in the countryside of Bahia the temperature ranges from $16^{\circ}$ to $40^{\circ} \mathrm{C}$ (mean $28^{\circ} \mathrm{C}$ ) in the driest quarter, but on the coast the temperature fluctuates between $21^{\circ}$ and $30^{\circ} \mathrm{C}$ (mean $25.5^{\circ} \mathrm{C}$ ) (INMET 2009). Regarding climate issues, the distribution of $P$. bahiensis appears to be affected by precipitation patterns, because the climatic variable with highest contribution to the model was precipitation in the driest quarter. The association of this variable with the mean monthly temperature range (BIO $2=14.2 \%$ ) establishes a potentially smaller predicted area of higher occurrence for $P$. bahiensis. These factors could explain the restricted distribution area of the species in the Atlantic Rainforest biome. This assumption could be better confirmed with the inclusion of other types of environmental variables in the SMD analysis.

The outcome values represented a good evaluation of the model prediction and are consistent with comparative evaluations of arachnids made by Acosta (2008) and RuBio et al. (2010). In addition, considering the known records, the predicted range looks quite similar to the expected distribution, mainly related to the restricted distribution area and the endemism of $P$. bahiensis in the Atlantic Forest biome.

This study also extends the known distribution range of $P$. bahiensis from the Northern coast of Bahia to the north of Espírito Santo, in Brazil, between $12^{\circ} 33^{\prime} 04.75^{\prime \prime} \mathrm{S}-37^{\circ} 59^{\prime} 16.98^{\prime \prime} \mathrm{W}$ and $19^{\circ} 23^{\prime} 00.67^{\prime \prime} \mathrm{S}-40^{\circ} 04^{\prime} 33.27^{\prime \prime} \mathrm{W}$. The habitats where this species lives have been drastically reduced and modified by human activities during the last century. The Restinga has been mainly modified by urbanization and tourism and the Ombrophilous Forest mostly by farming (NASCIMENTO 1993, Aв'SABER 2003). The results obtained herein indicate that $P$. bahiensis is distributed in a strategic conservation area of Atlantic Forest, and its range covers 11 Units designed for the conservation of animals, plants and traditional communities.

Other known collecting surveys of spiders in the predicted distribution area of $P$. bahiensis were carried out in fragments of Atlantic Rainforest in Ilhéus and Reserva Biologica de Una (Dias 2004, Dias et al. 2005b) and in Salvador (BEnaTi et al. 2010, Peres et al. 2010, Mendes Carvalho et al. 2010). These field surveys generally studied soil and leaf litter spiders using pitfall traps, Berlese funnel or Winkler extractor. PinTo-Leite et al. (2008) sampled spiders in Mata de São João by beating on bushes and by performing visual searches followed by hand collecting during the day. Oliveira-Alves et al. (2005) sampled spiders in Parque Metropolitano de Pituaçu, an Atlantic forest remnant in Salvador using nocturnal hand collection and foliage beating. Each of these sites has records of $P$. bahiensis, but those studies did not record the species, probably due to their rarity or because of the sampling methods used. Ctenids such as P. bahiensis and other wandering spiders are mainly collected by nocturnal hand collection when they are foraging (JoCQué \& DiPPENAAR-SCHOEMAN 2007).
The Atlantic forest is highly fragmented, and a large number of its endemic species are considered to be threatened with extinction mainly because more than $80 \%$ of the fragments are less than 50 ha and almost $50 \%$ of the forest are highly affected by anthropogenic activities (Metzger 2009). The Atlantic Forest fragments in the city of Salvador are considered important refuges for different kinds of organisms (Rodrigues et al. 1993, Brown JR \& Freitas 2003). Following the pattern of other regions of the Brazilian Atlantic coast, these fragments differ in size, conservation and human disturbance (РіскетT \& CADENASSO 2006). The adequate conservation actions for reducing the negative effects of the loss of Atlantic forest and its fragmentation emphasizes the need for having good ecological indicators for the establishment of conservation management plans (Metzger 2009, Pardin et al. 2009). Furthermore, remnant size and connectivity are considered the most important factors affecting the survival of species in fragmented landscapes, where groups with low dispersal capacity are particularly sensitive to the reduction of the fragmented area or to connection by thin corridors (METZGer et al. 2009).

Modeling refuges are considered effective for predictions of the distribution patterns of species and genetic endemism in Atlantic forest taxa (e.g., sloths, lizards, pitvipers, woodcreepers), as well as for low-dispersal Rainforest specialist taxa elsewhere (Graham et al. 2006). Carnaval \& Moritz (2008) studied the modeling of Pleistocene Atlantic Rainforest and proposed two important refuges situated in the states of Bahia and Pernambuco. They predicted that sampling efforts of the underexplored Bahia refuge will reveal high endemism at both species and generic levels. Phoneutria bahiensis could be considered part of the relic species group of living organisms from both Pleistocene refuges, supporting its condition as an endemic species.

Considering our results, the expected distribution of $P$. bahiensis is consistent with the known records and its range agrees with our predictions that this rare species is mostly restricted to the Atlantic Rainforest in northeastern Brazil. In Salvador, there are large remnants such as Parque Metropolitano da Lagoa e Dunas do Abaeté (1800 ha) and Parque Metropolitano de Pituaçu (425 ha), which may have better conditions for the establishment of management plans to preserve endemic and threatened species as $P$. bahiensis.

The importance of arthropods as indicators of small disturbance has been studied in the Brazilian Atlantic Rainforest (Uehara-Prado et al. 2009, Bragagnolo et al. 2007). Other species of the genus, for instance P. nigriventer (Keyserling, 1891) and P. keyserlingi (F.O.P.-Cambridge, 1897) are both recorded from urban areas or habitats with human activities (Sıмó \& BResCovit 2001). Field observations indicate that $P$. bahiensis is not synanthropic and is very sensitive to human impact. This species only occurs in protected fragments of the Atlantic Rainforest (DiAs et al. 2005a). The high vulnerability of this species to changes that affect the natural habitat and its ende- 
mism suggest that $P$. bahiensis is a promising bioindicator of human impact over the Atlantic Rainforest (Ombrophilous Forest and Restinga). The fast fragmentation of this biome requires the urgent implementation of proposals for the conservation and future survival of this species. In this sense, further studies on this species should focus on ethological and ecological aspects, and additional new field surveys that increase the number of records and provide new information concerning variables such as vegetation, soil, altitude, synanthropy and climatic change that can be incorporated into new model of distribution.

\section{ACKNOWLEDGMENTS}

We thank Clarissa Pinto-Leite, Marcelo Peres, Moacir Tinoco, and Henrique Ribeiro, for their help with the data and collection of the specimens. We are indebted to Fernando PérezMiles and Cristina Rheims for their useful comments to the manuscript and to Anita Aisenberg, Moacir Tinoco, and Victor Townsend for the revision of the English version. We thank Álvaro Laborda and Carolina Torranza for their help with the edition of the maps. We are grateful to Graciela Olazabal and Silvia Rodríguez by their help with the bibliography. Thanks are also extended to three anonymous referees who improved the manuscript. To CNPq (ADB, \# 300169/1996-5).

\section{LITERATURE CITED}

AB'SABER, A. 2003. Os domínios de natureza no Brasil, potencialidades paisagísticas. São Paulo, Ateliê Editora, 160p.

Andrewartha, H.G. \& L.C. BirCh. 1984. The ecological web: more on the distribution and abundance of animals. Chicago, University of Chicago Press, 520p.

Acosta, L.E. 2008. Distribution of Geraecormobius sylvarum (Opiliones, Gonyleptidae): Range modeling based on bioclimatic variables. Journal of Arachnology 36: 574-582.

BaAsch, D.M.; A.J. Tyrea; J.J Millspaughb; S.E. Hygnstroma \& K.C. VerCAUTEREN. 2010. An evaluation of three statistical methods used to model resource selection. Ecological Modelling 221: 565-574.

Benati, K.; M.C.L. Peres; M.S. Tinoco; A.D. Brescovit. 2010. Influência da estrutura de habitat sobre aranhas de serrapilheira em dois pequenos fragmentos de mata atlântica. Neotropical Biology and Conservation 5: 39-46. doi: 10.4013/nbc.2010.51.06

Benito de Pando, B. \& J. Peñas de Giles. 2007. Aplicación de modelos de distribución de especies a la conservación de la biodiversidad en el sureste de la Península Ibérica. GeoFocus (Artículos), Revista Internacional de Ciencia y Tecnología de la Información Geográfica 7: 100-119.

Benito, B.M.; M.M. Martínez-Ortega; L.M. Muñoz; J. Lorite \& J. PeÑas. 2009. Assessing extinction-risk of endangered plants using species distribution models: a case study of habitat depletion caused by the spread of greenhouses. Biodiversity Conservation 18: 2509-2520.

Bragagnolo, C.; A.A. Nogueira; R. Pinto-Da-Rocha \& R. Pardini. 2007. Harvestmen in an Atlantic forest fragmented landscape: Evaluating assemblage response to habitat quality and quantity. Biological Conservation 139: 389-400.

Brazil, T.K.; C.M. Pinto-Leite; L.M. Almeida-Silva; R.M. Lira-DASilva \& A.D. Brescovit. 2009. Aranhas de importância médica do Estado da Bahia, Brasil. Gazeta Médica da Bahia 79: 32-37.

Brito, J.C.; A.L. Acosta; F. Álvares \& F. Cuzin. 2009. Biogeography and conservation of taxa from remote regions: an application of ecological-niche based models and GIS to North-African Canids. Biology Conservation 142: 3020-3029.

Brooks, T.; J. Tobias \& A. BALmFord. 1999. Deforestation and bird extinctions in the Atlantic Forest. Animal Conservation 2: 211-222.

Brown JR, K.S. \& A.V.L. Freitas. 2003. Butterfly communities of urban forest fragments in Campinas, São Paulo, Brazil: structure, environment correlates, and conservation. Journal of Insect Conservation 6: 217-231.

Carnaval, A.C. \& C. Moritz. 2008. Historical climate modeling predicts patterns of current biodiversity in the Brazilian Atlantic forest. Journal of Biogeography 35: 1187-1201.

Carroll, C. 2010. Role of climatic niche models in focal-speciesbased conservation planning: Assessing potential effects of climate change on Northern Spotted Owl in the Pacific Northwest, USA. Biological Conservation 143: 1432-1437.

Ciliberti, P.; H. De Jong; A.S. Marieke; P.A. Verweij \& W.R.B. Heitmans. 2009. Ecological niche models for four native cockroach species (Blattaria: Blattellidae: Ectobiinae) in the Netherlands. Contributions to Zoology 78: 149-156.

De Mas, E.; G. Chust; J.L. Pretus \& C. Ribera. 2009. Spatial modelling of spider biodiversity: matters of scale. Biodiversity Conservation 18: 1945-1962.

Dias, M.A.; K.R. Benati \& M.C.L. Peres. 2005a. Ampliação da Distribuição Geográfica de Phoneutria bahiensis Simó \& Brescovit, 2001 (Ctenidae: Cteninae) no Estado da Bahia, Brasil. Biota Neotropica 5: 1-3.

DiAs, M.F.R. 2004. Levantamento das aranhas de solo (Arachnida: Araneae) na Reserva Biológica de Una, Bahia, Brasil. Sitientibus série Ciências Biológicas 4: 3-6.

Dias, M.F.R.; A.D. Brescovit \& M. Menezes. 2005b. Aranhas de solo (Arachnida: Araneae) em diferentes fragmentos no sul da Bahia, Brasil. Biota Neotropica 5:1-8.

Elith, J. \& J.R. Leathwick. 2009. Species Distribution Models: Ecological Explanation and Prediction Across Space and Time. Annual Review of Ecology, Evolution, and Systematics 40: 677-697.

Ferrier, S.; W. Graham; J. Pearce \& M. Drielsma. 2002. Extended statistical approaches to modelling spatial pattern in biodiversity in northeast New SouthWales. I. Species-level modelling. Biodiversity and Conservation 11: 2275-2307. 
Fielding, A.H. \& J.F. Bell. 1997. A review of methods for the assessment of prediction errors in conservation presence/ absence models. Environmental Conservation 24: 38-49.

FrankLIN, J. 2010. Moving beyond static species distribution models in support of conservation Biogeography. Diversity and Distributions 16: 321-330.

Gallien, L.; T. Münkemüller; C.H. Albert; I. Boulangeat \& W. THUILler. 2010. Predicting potential distributions of invasive species: where to go from here?. Diversity and Distributions 16: 331-342.

GASTON, K.J. 1996. Species richness: measure and measurement. Biodiversity: a biology of numbers and difference. Oxford, Blackwell Science, 113p.

Graham, C.H. \& R.J. Hijmans. 2006. A comparison of methods for mapping species richness. Global Ecology and Biogeography 15: $578-587$

Graham, C.H.; C. Moritz \& S.E. Williams. 2006. Habitat history improves prediction of biodiversity in rainforest fauna. Proceedings of the National Academy of Science 103: 632-636.

Guisan, A. \& N.E. Zimmermann. 2000. Predictive habitat distribution models in ecology. Ecological Modelling 135: 147186.

Guisan, A.; O. Broennimann; R. Engler; M. Vust; N.G. Yoccoz; A. LEHMANN \& N.E. ZIMMERMANN. 2006. Using niche-based models to improve the sampling of rare species. Conservation Biology 20: 501-511. doi: 10.1111/j.1523-1739.2006.00354.

Hanley, J.A. \& B.J. McNeil. 1982. The meaning and use of the area under a receiver operating characteristic (ROC) curve. Radiology 143: 29-36.

Hernández, P.A.; C.H. Graham; L.L. Master \& D.L. Albert. 2006. The effect of sample size and species characteristics on performance of different species distribution modeling methods. Ecography 29: 773-785.

Hijmans, R.J.; S.E. Cameron; J.L. Parra; P.G. Jones \& A. Jarvis. 2005a. Very high resolution interpolated climate surfaces for global land areas. International Journal of Climatology 25: 1965-1978.

Hijmans, R.J.; L. Guarino; A. Jarvis; R. O’Brien; P. Mathur; C. Bussink; M. Cruz; I. Barrantes \& E. Rojas. 2005b. DIVA-GIS. version 5.2. Available online at: http://www.diva-gis.org [Accessed: 17/08/2010]

INMET. Instituto Nacional de Meteorologia. 2009. Previsão Climática: Prognóstico Climático Trimestral. Available online at: http://www.inmet.gov.br/html/prev_climatica [Accessed: 17/08/2010].

Jocqué, R. \& A.S. Dippenaar-Schoeman. 2007. Spider families of the World. Tervuren, Belgium, Royal Museum for Central Africa, 336p.

KADMON, R.; O. FARBER \& A. DANIN. 2003. A systematic analysis of factors affecting the performance of climatic envelope models. Ecological Applications 13: 853-867.

Kumar, S. \& T.J. STOHLgREn. 2009. Maxent modeling for predicting suitable habitat for threatened and endangered tree
Canacomyrica monticola in New Caledonia. Journal of Ecology and Natural Environment 1: 94-98.

Liu, C.; P.M. Berry; T.P. Dawson \& R.G. Pearson. 2005. Selecting thresholds of occurrence in the prediction of species distributions. Ecography 28: 385-393.

LONDSDALE, W.M. 1988. Predicting the amount of litterfall in forest in the world. Annals of Botany 61: 319-324.

Machado, A.B.M.; A.D. Brescovit; O.H.H. Mielke; M.M. Casagrande; F.A. Silveira; F.P. Ohlweiler; D. Zeppeline; M. De Maria \& A.H. Wieloch. 2008. Panorama Geral dos Invertebrados Terrestres Ameaçados de Extinção, p.303-487. In: A.B.M. MACHADO; G.M. DRummond \& A.P. PAglia (Eds). Livro Vermelho da fauna brasileira ameaçada de extinção. Belo Horizonte, Ministério do Meio Ambiente, Fundação Biodiversitas.

Marengo J.A. 2008. Vulnerabilidade, impactos e adaptação à mudança do clima no semi-árido do Brasil. Parcerias Estratégicas: 43-72.

Martins, R. \& R. Bertani. 2007. The non-Amazonian species of the Brazilian wandering spiders of the genus Phoneutria Perty, 1833 (Araneae: Ctenidae), with the description of a new species. Zootaxa 1526: 1-36.

Mendes Carvalho, D.; M.C.L. Peres; M.A. Dias; M.C. Requião Queiroz \& T. Trindade Ferreira. 2010. Araneofauna de serrapilheira em um fragmento de Mata Atlântica do nordeste brasileiro: estudo comparativo entre dois métodos de coleta. Neotropical Biology and Conservation 5: 93-100.

Metzger, J.P. 2009. Conservation issues in the Brazilian Atlantic forest. Biological Conservation 142: 1138-1140.

Metzger J.P.; A.C. Martensen; M. Dixo; L.C. Bernacci; M.C. Ribeiro; A.M.G. Teixeira \& R. Pardini. 2009. Time-lag in biological responses to landscape changes in a highly dynamic Atlantic forest region. Biological Conservation 142:1166-1177.

MMA. 2008. Livro Vermelho da Fauna Brasileira Ameaçada de Extinção, Brasil. Brasília, Ministério do Meio Ambiente. Available online at: http://www.mma.gov.br [Accessed: 17/III/2010].

Nascimento, D.A.C. Do. 1993. Reserva da biosfera da Mata Atlântica: Análise de Dados. Qualidade Ambiental. Salvador, Secretaria de Planejamento, Ciências e Tecnologia do Estado da Bahia, p 58-61.

Oliveira-Alves, A.; M.C.L. Peres; M. Dias; G.S. Cazais-Ferreira \& L.R.A. Souto. 2005. Estudo das comunidades de aranhas (Arachnida: Araneae) em ambiente de mata atlântica no parque metropolitano de Pituaçu - PMP, Salvador, Bahia. Biota Neotropica 5: 1-8.

Pardini, R.; D. Faria; G.M. Accacio; R.R. Laps; E. Mariano-Neto; M.L.B. Paciencia; M. Dixo \& J. Baumgarten. 2009. The challenge of maintaining Atlantic forest biodiversity: A multi-taxa conservation assessment of specialist and generalist species in an agro-forestry mosaic in southern Bahia. Biological Conservation 142: 1178-1190.

Parmesan, C. 2006. Ecological and evolutionary responses to recent climate change. Annual Review of Ecology, Evolution, and 
Systematics 37: 637-669.

Pearson, R.G.: C.J. Raxworthy; M. Nakamura \& A. Townsend Peterson. 2007. Predicting species distributions from small numbers of occurrence records: a test case using cryptic geckos in Madagascar. Journal of Biogeography 34: 102-117.

Peres, M.C.L.; J.P. Souza-Alves; K.R. Benati; M.A. Dias; A.O. Alves; C.O. MÁximo \& A.D. Brescovit. 2010. Distribution of leaf litter spider (Araneae) in treefall gaps and on adjacent forest in an Atlantic Rainforest remnant in Bahia State, Brazil. Revista Biociências, UNITAU 16: 109-115.

Phillips, S.J.; R.P. Anderson \& R.E. Schapire. 2006. Maximum entropy modeling of species geographic distributions. Ecological Modeling 190: 231-259.

Pickett, S.T.A. \& M.L. Cadenasso. 2006. Advancing urban ecological studies: frameworks, concepts, and results from the Baltimore ecosystem study. Australian Journal of Ecology 31: 114-125.

Pinto-Leite, C.M.; A.C. Guerrero \& T.K. Brazil. 2008. Non-random patterns of spider species composition in an Atlantic rainforest. Journal of Arachnology 36: 448-452.

Pires, L.A.; R.M. Britez; G. Martel \& S.N. Pagano. 2006. Produção, acúmulo e decomposição da serapilheira em uma restinga da Ilha do Mel, Paranaguá, PR, Brasil. Acta Botanica Brasilica 20: 173-184.

Platnick, N.I. 2010. The world spider catalog, version 11.0. American Museum of Natural History. Available online at: http://research.amnh.org/entomology/spiders/catalog/ index.html (Accessed: 17/X/2010).

RizzinI, C.T. 1997. Tratado de Fitogeografia do Brasil: aspectos ecológicos, sociológicos e florísticos. Rio de Janeiro, Âmbito Cultural Edições, 747p.

Rodrigues, J.J.S.; K.S. Brown Jr \& A. Ruszczyk. 1993. Resources and conservation of Neotropical butterflies in urban forest fragments. Biological Conservation 64: 3-9.

Rubio, G.; E.N.L. Rodrigues \& L. Acosta. 2010. Description of the male of the spider Dubiaranea difficilis (Araneae: Linyphiidae), with new records and modeling of its potential geographic distribution. Zootaxa 2405: 55-62.

Scheer, M.B.; G. Gatti; C. Wisniewski; A.Y. Mocochinski; A.T. Cavassani; A. Lorenzetto \& F. Putini. 2009. Patterns of litter production in a secondary alluvial Atlantic Rain Forest in southern Brazil. Revista Brasileira de Botânica 32: 805-817.

Sexton, J.P.; P.J. Mcintyre; A.L. Angert \& K.J. Rice. 2009. Evolution and ecology of species range limits. Annual Review of Ecology, Evolution, and Systematics 40: 415-436.

Simó, M. \& A.D. Brescovit. 2001. Revision and cladistic analysis of the Neotropical spider genus Phoneutria Perty, 1833 (Araneae, Ctenidae), with notes on related Ctenidae. Bulletin of the British Arachnological Society 12: 67-82.

Stockman, A.K.; D.A. BeAmer \& J.E. Bond. 2006. An evaluation of a GARP model as an approach to predicting the spatial distribution of non-vagile invertebrate species. Diversity and Distributions 12: 81-89.

Uehara-Prado, M.; J. De Oliveira Fernandes; A. De Moura Bello; G. Machado; A.J. Santos; F. Zagury VaZ-De-Mello \& A.V. Lucci FreItAs. 2009. Selecting terrestrial arthropods as indicators of small-scale disturbance: A first approach in the Brazilian Atlantic Forest. Biological Conservation 142: 1220-1228.

VINK, C.J.; J.G.B. Derraik; C.B. PhilLIPS \& P.J. Sirvid. 2011. The invasive Australian redback spider, Latrodectus hasseltii Thorell 1870 (Araneae: Theridiidae): current and potential distributions, and likely impacts. Biological Invasions 13: 1003-1019.

Wisz, M.S.; R.J. Hijmans; J. Li; J.A.T. Peterson; C.H. Graham; A. Guisan \& Nceas Predicting Species Distributions Working Group. 2008. Effects of sample size on the performance of species distribution models. Diversity and Distributions 14: 763-773.

WoodWARd, F.I. 1987. Climate and plant distribution. Cambridge, Cambridge University Press, 190p.

Zhonglin, X.; Z. Chuanyan \& F. Zhaodong. 2009. A study of the impact of climate change on the potential distribution of Qinghai spruce (Picea crassifolia) in Qilian Mountains. Acta Ecologica Sinica 29: 278-285.

Submitted: 27.X.2010; Accepted: 17.VI.2011.

Editorial responsibility: Pedro Gnaspini 